\title{
Human Immunodeficiency Virus gag and protease: partners in resistance
}

\author{
Axel Fun ${ }^{1}$, Annemarie MJ Wensing ${ }^{1}$, Jens Verheyen ${ }^{2}$ and Monique Nijhuis ${ }^{1 *}$
}

\begin{abstract}
Human Immunodeficiency Virus (HIV) maturation plays an essential role in the viral life cycle by enabling the generation of mature infectious virus particles through proteolytic processing of the viral Gag and GagPol precursor proteins. An impaired polyprotein processing results in the production of non-infectious virus particles.

Consequently, particle maturation is an excellent drug target as exemplified by inhibitors specifically targeting the viral protease (protease inhibitors; PIs) and the experimental class of maturation inhibitors that target the precursor Gag and GagPol polyproteins. Considering the different target sites of the two drug classes, direct cross-resistance may seem unlikely. However, coevolution of protease and its substrate Gag during PI exposure has been observed both in vivo and in vitro. This review addresses in detail all mutations in Gag that are selected under PI pressure. We evaluate how polymorphisms and mutations in Gag affect PI therapy, an aspect of PI resistance that is currently not included in standard genotypic PI resistance testing. In addition, we consider the consequences of Gag mutations for the development and positioning of future maturation inhibitors.
\end{abstract}

Keywords: HIV, Particle maturation, Protease inhibitors, Maturation inhibitors, Gag mutations, Resistance, Cross-resistance

\section{Review}

HIV maturation

HIV is released from the host cell membrane as a noninfectious particle that is called the immature virion. After budding and release, the virion undergoes a dramatic structural rearrangement that results in fully infectious virus. Transition of the amorphous, non-infectious virion into the mature, infectious virion that is characterized by an electron-dense conical core is called maturation (Figure 1). This transition is triggered by the proteolytic cleavage of the Gag (Pr55 ${ }^{\mathrm{Gag}}$ ) and GagPol $\left(\operatorname{Pr} 160^{\mathrm{GagPol}}\right)$ precursor polyproteins by the viral enzyme protease (PR). Gag is cleaved into the structural proteins matrix (MA, p17), capsid (CA, p24) and nucleocapsid (NC, p7), p6 and two small spacer peptides (p1 and p2). Pol, which is translated as the GagPol polyprotein after a -1 nucleotide frameshift event, that occurs with a frequency of $5-10 \%$ [1], encodes the viral enzymes PR, reverse transcriptase (RT) and integrase (IN). Analysis of

\footnotetext{
* Correspondence: m.nijhuis@umcutrecht.nl

'Department of Virology, Medical Microbiology, University Medical Center Utrecht, HP G04.614, Heidelberglaan 100, Utrecht 3584 CX, The Netherlands Full list of author information is available at the end of the article
}

different Gag substrates revealed that HIV PR recognizes the asymmetric, 3-dimensional conformation of the Gag substrate, rather than a particular peptide sequence [2]. The peptides that form the different cleavage sites (CS) have a superimposable secondary structure, yielding the so-called substrate envelope which fits within the substrate binding pocket of the viral PR. However, each substrate has a unique structure, and there are subtle differences in the way the amino acids protrude from the substrate envelope. It is thought that these small differences in substrate structure impact affinity for the viral protease and contribute to the highly regulated and ordered stepwise process of viral maturation in which all the individual cleavages occur at different rates [3-6] (Figure 1). First, the scissile bond between $\mathrm{p} 2$ and $\mathrm{NC}$ (MA-CA-p2 $\downarrow$ NC-p1-p6) is cleaved, followed by separation of MA from CA-p2 (MA $\downarrow C A-p 2)$. Subsequently p6 is cleaved from NC-p1 (NC-p1 $\downarrow$ p6). Finally, the two small spacer peptides are removed in the rate-limiting cleavage steps $\mathrm{NC} \downarrow \mathrm{p} 1$ and $\mathrm{CA} \downarrow \mathrm{p} 2$, of which $\mathrm{CA} \downarrow \mathrm{p} 2$ is thought to be the final cleavage (Figure 1). This ordered cleavage is mainly regulated by those amino acids in the substrate that are in direct contact with the viral PR

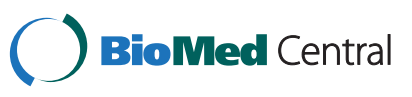




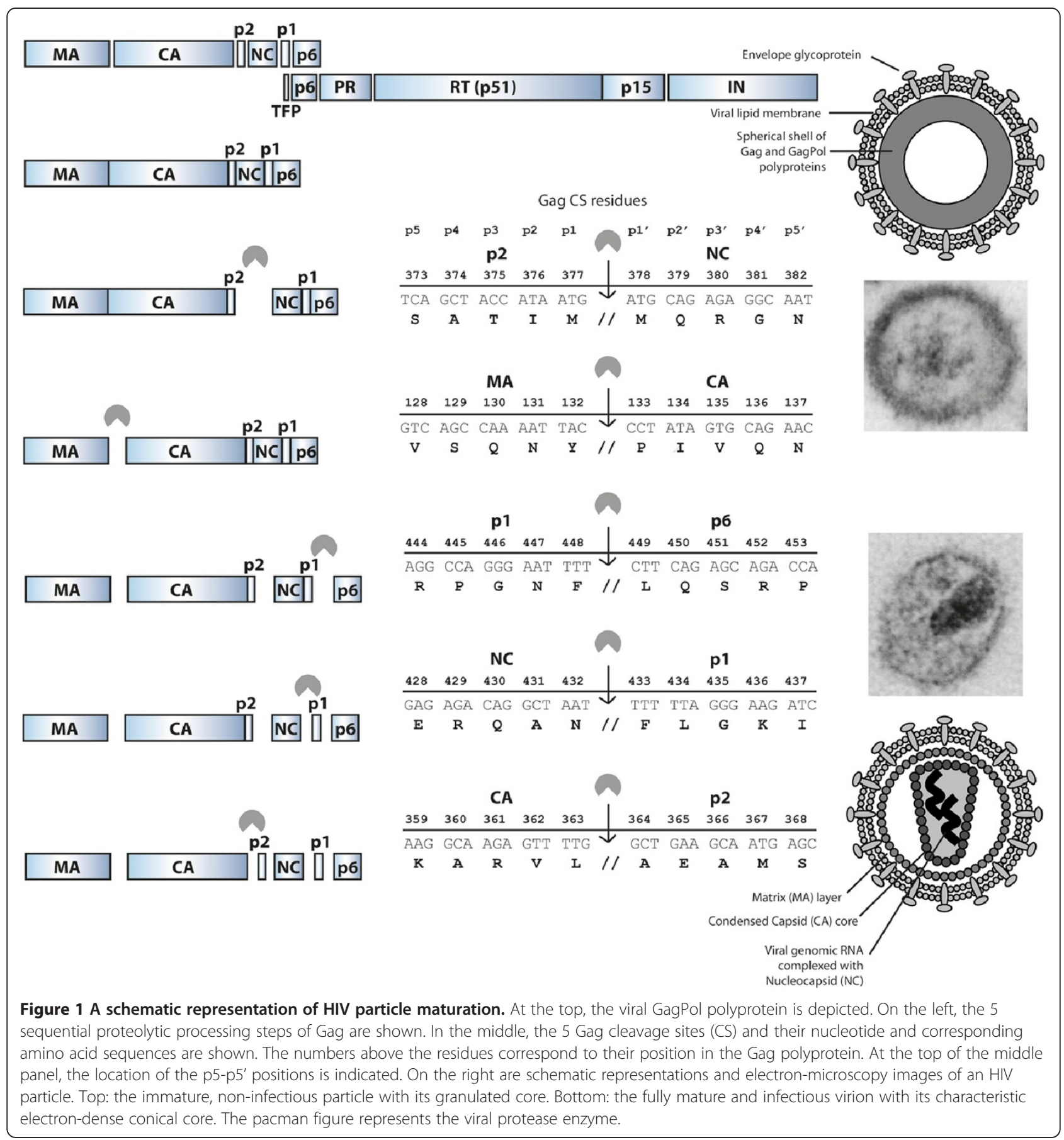

(p4-p3' position, Figure 1) [6-8]. Although most studies have focused on the impact of these substrate residues that are in direct contact with the viral PR, it has been demonstrated that the more distantly located p4' and p5' residues can also affect processing efficiency [9-13].

\section{HIV protease}

HIV protease is a member of the family of aspartic proteases and is a symmetrically assembled homodimer consisting of two identical subunits of 99 amino acids. Both subunits contribute catalytic residues to the active site (an aspartic acid at codon 25) [14,15]. The substrate binding pocket is at the center of the dimer and interacts with the different substrate sequences in the Gag and GagPol polyproteins. The mechanism that activates the viral PR, which is embedded in the GagPol polyprotein itself, is not yet fully understood. It is known however, that the viral $\mathrm{PR}$ is responsible for its own 
release from the precursor polyprotein (autoprocessing). Since PR is active only as a dimer, it is thought that autoprocessing is initiated by dimerization of two protease domains that are still embedded in the GagPol precursor. The initial cleavage is a transient, intramolecular event and the low occupancy of the embedded dimer configuration can explain its low enzymatic activity compared to the fully matured PR enzyme [16,17].

\section{Protease inhibitors}

Detailed structural knowledge of HIV PR and its substrate led to the development of specific protease inhibitors (PIs). To date, nine different PIs have been approved for clinical use: saquinavir (SQV), ritonavir (RTV), indinavir (IDV), nelfinavir (NFV), (fos)amprenavir (FPV/APV), lopinavir (LPV), atazanavir (ATV), tipranavir (TPV) and darunavir (DRV). All PIs, with the exception of tipranavir, are competitive peptidomimetic inhibitors, mimicking the natural substrate of the viral PR. The peptidomimetic inhibitors contain a hydroxyethylene core which prohibits cleavage by the viral PR [18-25]. Instead of a hydroxyethylene core, tipranavir contains a dihydropyrone ring as a central scaffold [26]. In general, all these compounds have been designed to bind to the substrate binding region of the mature viral PR dimer with high affinity, but they tend to occupy more space than the natural substrate. For tipranavir and darunavir, it has been demonstrated that they have a dual mechanism of inhibition as they also impede dimerization of the viral PR [27]. This may contribute to their antiviral potency and high genetic barrier towards resistance, although the impact of the anti-dimerization activity has not been elucidated yet.

Inhibition of the initial GagPol processing steps which involve self-cleavage of the embedded HIV PR from the GagPol polyprotein (autoprocessing) would prevent viral maturation at the earliest stages and therefore be an ideal drug target. However, all PIs have been developed to bind the active site of the mature PR dimer, and it was shown that the embedded HIV PR dimer is 10,000 fold less sensitive to RTV than the mature PR dimer [16]. More recently, two different groups demonstrated independently and using different assays, that of the nine approved PIs, DRV and SQV are the most potent inhibitors of autoprocessing. However, both inhibitors are still three orders of magnitude less active against the embedded dimer compared to the mature PR dimer [28,29].

Currently, first line highly active antiretroviral therapy (HAART) regimens usually consist of a combination of two nucleoside reverse transcriptase inhibitors (NRTIs) with either a non-nucleoside reverse transcriptase inhibitor (NNRTI), an integrase inhibitor, or a PI. Effective HAART has reduced HIV-related morbidity and mortality and greatly improved therapeutic success rates [30]. However, in the early days of PI therapy, high pill burden and related toxicity, low bioavailability and a low barrier to the emergence of resistance severely impaired effective treatment of HIV infected individuals. Resistance to PIs was usually associated with the selection of multiple mutations in the viral PR resulting in broad class cross-resistance. Since then, several strategies have been developed to improve clinical outcome and increase the barrier to development of PI resistance. Co-administration with ritonavir, an inhibitor of the cytochrome P450 3A4 isoenzyme, which is involved in the metabolism of all PIs, considerably improved the bioavailability and half-life of PIs [31] resulting in higher PI plasma concentrations with a reduced pill burden and related drug toxicity [32]. Another improvement was the development of second generation PIs that have an intrinsic higher genetic barrier to development of resistance, which are (fos)amprenavir, lopinavir, atazanavir, tipranavir and darunavir [20,23-26,33-36]. In patients on second generation PI based HAART and who have not received prior PI therapy, selection of primary resistance mutations in the viral PR is rare, even in case of therapy failure.

Evolution of PI resistance usually has a biphasic signature in which mutations develop initially in or near the substrate binding pocket of the viral PR. In fact, it has been shown that resistance mutations mainly develop where the PIs protrude beyond the substrate binding pocket at residues that are in direct contact with the inhibitor, but not with the natural substrate [37-39]. These mutations lower the affinity for the drug more than for the natural substrate, which decreases the susceptibility to the drug, resulting in a resistant virus. However, by changing the substrate binding region of the enzyme, the affinity for the natural substrate (Gag) is also slightly altered, often resulting in reduced viral replication [40-42]. In a second step, compensatory or secondary mutations can be selected that restore viral replication and/or enhance drug resistance. These mutations are found in the viral PR itself as well as in the Gag substrate and in particular, in the $\mathrm{NC} / \mathrm{p} 1$ and $\mathrm{p} 1 / \mathrm{p} 6$ cleavage sites $[9,12,43-49]$. It has also been shown that several Gag substrate mutations are primary drug resistance mutations that confer PI resistance in the absence of PR mutations $[10,50]$.

In this review we describe the results of a comprehensive search of the available literature investigating natural variation in Gag and coevolution of Gag and protease during protease inhibitor exposure. We provide a detailed overview of Gag mutations that are observed during PI exposure, both in vivo and in vitro and how they affect PI therapy and resistance. Furthermore, we evaluated the impact of these Gag mutations on the 
efficacy of the novel antiretroviral class of $\mathrm{CA} / \mathrm{p} 2$ maturation inhibitors.

\section{Natural variation of Gag cleavage sites}

Only a limited number of studies evaluated the natural variation within Gag and its cleavage sites and most data are from studies focusing on subtype B [51-58]. The limited data that are available suggest that the variation in non-B subtypes is greater than in subtype B $[52,53,56]$. All these studies show that the degree of conservation differs dramatically between individual amino acid positions as well as between the different cleavage sites as a whole (Table 1 ). Cleavage site $\mathrm{p} 2 / \mathrm{NC}$ is the most variable of the 5 Gag cleavage sites, followed by p1/p6, NC/ $\mathrm{p} 1, \mathrm{CA} / \mathrm{p} 2$ and finally MA/CA, which is the most conserved CS in subtype B isolates. Amino acids 369-371 in p2 are included in this table as they are important for $\mathrm{CA} / \mathrm{p} 2$ maturation inhibitor susceptibility, which will be described later in this review.

\section{Selection of Gag cleavage site mutations during protease inhibitor exposure}

During PI exposure, substitutions in all Gag CS have been described. Mutations in MA/CA (codon 128), NC/p1 (codons 431, 436 and 437) and p1/p6 (codons 449, 452 and 453) are observed most frequently in vitro and in vivo and have been shown to confer PI resistance (Table 2). The effect of these different CS mutations is described in detail below.

\section{MA/CA mutations}

Several mutations at MA codon 128 (V128T/A/del) were associated with exposure to PIs in vivo (FPV/ATV/r) [56]. In addition, substitution V128I was observed more frequently in subtype $G$ isolates from PI experienced patients compared to PI naïve patients [65]. Mutation V128I was also associated with virological rebound in patients on a boosted DRV containing regimen and was positively correlated with presence of PR mutation V32I [66]. It also has been selected in vitro with GS-8374, an experimental high genetic barrier PI [64].

\section{NC/p1 mutations}

$\mathrm{NC} / \mathrm{p} 1 \mathrm{CS}$ mutation A431V is the most frequently occurring Gag CS mutation during PI exposure. It has been observed in vivo during PI therapy with RTV [46,51,79,80], IDV [45,51], NFV [77], SQV [51,79], LPV [81] and was also associated with PI exposure in unspecified therapy or cross-sectional analyses $[10,55,57,78,82]$. It is often observed in combination with one or more of

Table 1 Natural variation of Gag cleavage sites in subtype B isolates

\begin{tabular}{|c|c|c|c|c|c|c|c|c|c|c|c|c|c|c|}
\hline & & & MA & & & // & & & $C A$ & & & & & \\
\hline HXB2 aа & V & $\mathrm{S}$ & Q & $N$ & $Y$ & $/ /$ & $P$ & I & $\mathrm{V}$ & Q & $N$ & & & \\
\hline position & 128 & 129 & 130 & 131 & 132 & // & 133 & 134 & 135 & 136 & 137 & & & \\
\hline \multirow[t]{2}{*}{ variability (\%) } & 3.5 & - & 4.3 & - & 3.5 & // & - & - & 0.9 & 0.9 & - & & & \\
\hline & & & CA & & & // & & & p2 & & & & & \\
\hline HXB2 aа & K & A & $\mathrm{R}$ & v & $L$ & // & A & E & A & M & A & Q & V & $\mathrm{T}$ \\
\hline position & 359 & 360 & 361 & 362 & 363 & // & 364 & 365 & 366 & 367 & 368 & 369 & 370 & 371 \\
\hline \multirow[t]{2}{*}{ variability (\%) } & 0.2 & 0.2 & 1.8 & 11.5 & 1.2 & // & - & - & - & - & 1.2 & 4.1 & 24.8 & 16.4 \\
\hline & & & p2 & & & // & & & NC & & & & & \\
\hline HXB2 аa & $S$ & A & $\mathrm{T}$ & । & M & // & M & Q & $\mathrm{R}$ & G & $N$ & & & \\
\hline position & 373 & 374 & 375 & 376 & 377 & // & 378 & 379 & 380 & 381 & 382 & & & \\
\hline \multirow[t]{2}{*}{ variability (\%) } & 36.3 & 32.6 & 42.7 & 23.6 & 1.8 & // & 5.5 & - & 40.9 & 5.5 & 2.1 & & & \\
\hline & & & NC & & & // & & & p1 & & & & & \\
\hline HXB2 aa & $\mathrm{E}$ & $\mathrm{R}$ & Q & A & N & // & $\mathrm{F}$ & L & G & K & I & & & \\
\hline position & 428 & 429 & 430 & 431 & 432 & // & 433 & 434 & 435 & 436 & 437 & & & \\
\hline \multirow[t]{2}{*}{ variability (\%) } & 2.3 & 3.5 & - & 0.5 & - & // & - & 0.1 & - & 6.3 & 5.5 & & & \\
\hline & & & p1 & & & // & & & p6 & & & & & \\
\hline HXB2 aа & $\mathrm{R}$ & $P$ & G & N & $\mathrm{F}$ & // & $L$ & Q & $S$ & $\mathrm{R}$ & $P$ & & & \\
\hline position & 444 & 445 & 446 & 447 & 448 & // & 449 & 450 & 451 & 452 & 453 & & & \\
\hline variability (\%) & - & 0.1 & - & - & - & // & 9.1 & - & 22.8 & - & 8.4 & & & \\
\hline
\end{tabular}

Data describing the natural variation at individual codons in the five Gag cleavage sites were pooled and the frequency of polymorphisms as compared to the HXB2 reference sequence was calculated. Only data describing subtype B isolates were included in the analysis. Codons $369-371$ in p2 are included because of their important role in CA/p2 maturation inhibitor susceptibility. A dash indicates $100 \%$ conservation. 
Table 2 All Gag mutations associated with PI exposure and/or resistance and maturation inhibitor resistance

\begin{tabular}{|c|c|c|c|c|}
\hline \multirow[t]{2}{*}{ Gag mutation } & \multicolumn{2}{|c|}{ Associated with PI exposure } & \multirow{2}{*}{$\begin{array}{l}\text { Associated with } \\
\text { PI resistance }\end{array}$} & \multirow{2}{*}{$\begin{array}{l}\text { Associated with } \\
\text { maturation inhibitor } \\
\text { resistance }\end{array}$} \\
\hline & in vivo & in vitro & & \\
\hline
\end{tabular}

\section{$\underline{\mathrm{MA}}$}

E12K

G62R

L75R

R76K

Y79F

T81A

K112E

\section{CS MA/CA}

V128I/T/A/del

Y132F

\section{$\underline{C A}$}

M200I

H219Q/P

\section{CS CA/p2}

A360V

V362I

L363M/F/C/N/Y

S368C/N

p2

$\mathrm{Q} 369 \mathrm{H}$

V370A/M/del

T371del

\section{CS p2/NC}

$\begin{array}{ll}\mathrm{S} 373 \mathrm{P} / \mathrm{Q} / \mathrm{T} & \text { yes }[51,54,78] \\ \mathrm{A} 374 \mathrm{P} / \mathrm{S} & \text { yes }[78] \\ \mathrm{T} 375 \mathrm{~N} / \mathrm{S} & \text { yes }[46,78] \\ \text { I376V } & \text { yes }[46,51] \\ \mathrm{G} 381 \mathrm{~S} & \text { yes }[46]\end{array}$

NC

I389T

V390A/D

I401TN

R409K

\section{CS NC/p1}

E428G

Q430R

A431V

K436E/R

I437TN

yes $[56,65,66]$

yes $[46,67]$

yes [46]

yes [54]

yes [54]

yes [77]

yes [77]

yes [77]

yes [66]

yes $[10,55,82]$ yes $[10,45,46,51,55,57,77-83]$

yes $[10,45,46,51,55,78,82,86]$ yes [68]

yes [61]

yes $[51,54]$

yes $[59,60]$

yes [61]

yes $[59,60]$

yes [64]

yes $[59,60,64]$

yes [62]

yes [62]

yes [62]

yes [64]

yes [64]

yes [64]

yes $[72,74]$

yes $[69,70,72,74-76]$

yes $[72,74,76]$ yes $[69,70]$

yes $[69,71-74]$

yes [69] yes $[59,60]$

yes [64]

yes [59-61,64]

yes [44]

yes $[10,44,84,85] \quad$ yes $[13,55,81]$

yes $[10] \quad$ yes $[10,13,55]$

yes $[10,61] \quad$ yes $[10,13,55]$ 
Table 2 All Gag mutations associated with PI exposure and/or resistance and maturation inhibitor resistance (Continued)

\begin{tabular}{|c|c|c|c|}
\hline CS p1/p6-gac & & & \\
\hline L449F/PN & yes $[9,45,46,55-57,67,77,79,80,82,86]$ & yes $[44,49,85,87]$ & yes [55] \\
\hline $\mathrm{S} 451 \mathrm{~T} / \mathrm{G} / \mathrm{R}$ & yes $[55,66]$ & & \\
\hline R452S/K & yes $[55,66,79,82]$ & yes [87] & yes [55] \\
\hline $\mathrm{P} 453 \mathrm{~A} / \mathrm{L} / \mathrm{T}$ & yes $[9,55,57,77,81,82][67]$ & yes $[84,87]$ & yes $[9,55]$ \\
\hline$\underline{\text { p6-gag }}$ & & & \\
\hline E468K & & yes [59] & \\
\hline Q474L & yes [77] & & \\
\hline A487S & yes [77] & & \\
\hline P497L & yes [77] & & \\
\hline p6-pol & & & \\
\hline V484G/I/P/S & yes [88] & & \\
\hline CS TFP/p6po & & & \\
\hline D437N & yes $[56,64]$ & & \\
\hline
\end{tabular}

the following PI resistance mutations in the viral PR: L24I, M46I/L, I50L, L76V, V82A/T/F and I84V. In vitro, mutation A431V was selected during exposure to RTV [10,84], LPV [85] and experimental PI BILA 2185 BS [44]. Mutation A431V confers resistance to all PIs except DRV $[10,55]$ and can be considered a primary PI resistance mutation as it confers PI resistance in the absence of mutations in the viral PR [10]. The level of resistance caused by this mutation is comparable to that of single PI resistance mutations in PR (M46I and V82A) [81].

Substitutions at amino acids 436 and 437 in the $\mathrm{NC} / \mathrm{p} 1 \mathrm{CS}$ have been observed during PI therapy with RTV [46,51], IDV [45], SQV [51] and were associated with PI exposure in unspecified therapy or crosssectional analyses $[10,55,78,82,86]$. Mutations at Gag position 436 are associated with PR mutation V82A and mutation I437V with PR mutations: I54V, V82F/T/S and I84V. They have been selected in vitro with experimental high genetic barrier PIs (RO033-4649; 436E + 437T, 437T and 437V [10] and (GRL-02031; 437T [61]). These mutations confer PI resistance and mutation $1437 \mathrm{~V}$ and the double mutation K436R + I437T also confer PI resistance in the absence of PR mutations [10,13,55]. Mutation $1437 \mathrm{~V}$ alone results in low-level PI resistance, but the double mutation $\mathrm{K} 436 \mathrm{E}+\mathrm{I} 437 \mathrm{~T}$ has a greater impact on PI susceptibility and confers slightly more resistance than mutation A431V [13].

\section{p1/p6 mutations}

Mutations in the p1/p6 CS and especially substitutions at codons 449, 452 and 453 are also often observed during PI therapy $[9,45,46,55-57,77,79-82,86]$.

Mutations $\mathrm{L} 449 \mathrm{~F} / \mathrm{V} / \mathrm{P}$ have been associated with PI therapy in a number of cross-sectional studies (Table 2) and have been directly related to treatment with RTV [80], IDV [45],NFV [67], FPV, ATV [56], SQV [46,56] and APV [9]. Mutation L449F often occurs in combination with PR mutations D30N/N88D, I50V and I84V and mutation $\mathrm{L} 449 \mathrm{~V}$ is observed with $\mathrm{PR}$ mutations I54L/M/S/T/A.

L449F has been selected in vitro using LPV [85], APV [49], and experimental PIs BILA 1906 BS, BILA 2185 BS [44] and GW640385 [87]. Alone, mutation L449F has no effect on PI susceptibility, but in combination with mutations in the viral PR it affects inhibitor resistance. Combined with D30N/N88D, it decreases susceptibility to IDV, SQV, APV and TPV. In combination with V82A or V82A/L90M, mutation L449F decreases susceptibility to all PIs (DRV was not tested). Interestingly, when combined with PR mutation I50V, it induces hypersusceptibility to IDV, LPV and especially RTV [87].

Amino acid substitutions at position 452 have been associated with exposure to RTV, SQV [79], DRV [66] and in two cross-sectional studies [55,82]. In vivo, mutations at this position associate with PR mutations D30N/ N88D, I50V and I84V [55]. In vitro, mutation P452K has been selected with experimental PI GW640385 [87]. In combination with PR substitutions I84V or I84V/L90M, R452 mutations decrease susceptibility to all PIs except TPV (DRV was not tested) [55].

Mutations at position 453 have been associated with PI exposure in vivo to APV [9], LPV [81], NFV [57,67], RTV, IDV and SQV [57]. It is often seen together with PR mutations D30N, I50V, I84V, N88D and L90M [9,55,57]. In vitro, mutation $\mathrm{P} 453 \mathrm{~L}$ has only been described being selected with IDV and P453T with experimental PI GW640385 [87]. P453L does not confer resistance on its own, but enhances PI resistance in 
combination with PR mutation I50V $[9,55]$ and I84V to NFV, APV and SQV and to all PIs in combination with L90M (DRV not tested) [55].

\section{Gag CS mediated PI resistance}

The observed association between PI exposure and Gag CS mutations signifies the close relationship of the viral PR and the Gag CSs and their contribution to escape PI pressure. The effect of Gag CS mutations on PI susceptibility has been studied in detail. Structural and functional analyses of the processing efficiencies of wild type or mutant substrates showed improved processing and/ or higher predicted binding affinities for the mutant substrates $[9,11,37,89,90]$. Enhanced processing of Gag is believed to shift the equilibrium of protease inhibitor/ Gag substrate with the viral PR in favour of the Gag substrate and thereby confers resistance. This proposed mechanism of Gag CS mediated PI resistance is supported by studies that show altering just one CS (NC/p1 in these studies) also affects the processing efficiency at other CSs and thereby the entire substrate processing cascade [13,91]. Nevertheless, the difference in affinity of the viral PR for either the substrate or the PIs seems to contradict this explanation. Whereas the PR's affinity constant for the PIs is thought to be in the low nanomolar range, the affinity constant for the natural substrates is in the millimolar range [92]. How a small shift in equilibrium induced by CS mutations can negate this million fold difference in binding affinity is not fully understood. One possible explanation that is offered comes from the stoichiometry of viral PR relative to its substrate, as it is present at the site of assembly and maturation [93]. The ratio between PR and natural substrate compared to PR and PI might be very different at the site of HIV maturation than in the cell-free environment used for in vitro enzymatic analysis which could strongly affect the actual in vivo kinetics [12].

\section{Selection of Gag non-cleavage site mutations during protease inhibitor exposure}

Besides HIV-1 CS mutations, accumulation of non-CS mutations during PI therapy has been observed in all Gag proteins (MA, CA, NC, p6) as well as in spacer peptide $\mathrm{p} 2$ (Table 2). Additionally, several non-CS mutations in Gag have been identified in vitro to contribute to PI resistance in the presence of PR mutations $[34,59,64]$, but can also mediate reduced PI susceptibility in the absence of PR mutations [62,94]. The impact of single non-CS Gag mutations on PI susceptibility has not been investigated, but combinations of non-CS Gag substitutions have been shown to affect both viral replication capacity and PI susceptibility $[59,60,62,77]$. The underlying mechanism of non-CS mediated resistance is not well understood. Since Gag non-CS mutations did not accumulate in functional related regions but were found throughout the whole Gag precursor protein, multiple mechanisms are likely to be involved and different per gene-segment.

\section{Matrix}

Substitutions in MA have been associated with virological failure against boosted LPV containing therapy (R76K, Y79F and T81A) [62,63]. They have been selected in vitro with APV (E12K and L75R $[59,60]$ ) and experimental PIs GRL-02031(G62R [61]) and GS-8374 (K112E) [64]). The mechanism of MA-mediated resistance remains elusive, but it is speculated that MA mutations change the multimerization of viral Gag. Another mechanism was suggested in a study demonstrating that changes in the tertiary protein structure of the Gag precursor proteins, caused by three mutations in the matrix protein, conferred drug resistance [62]. The three resistance associated residues (R76K, Y79F and T81A) are located in an alpha helical structure within MA, and the mutations result in loss of certain hydrogen bonds and thus more flexibility around the helix. It is hypothesized that the greater flexibility increases either the affinity or the availability/accessibility of the MA-CA CS with respect to the PR.

\section{Capsid}

Mutations in CA have not been associated with virological failure to PI therapy, but substitutions M200I (with GS-8374 [64]) and H219Q/P (with GS-8374 [64] and APV $[59,60]$ ) have been selected during PI exposure in vitro. The effect of mutation M200I is unknown, but substitutions at codon $\mathrm{H} 219$ interfere with binding of cyclophilin A and possibly reduce the requirement for cyclophilin A for efficient replication and thereby increase viral replication [59].

\section{p2}

Mutations in p2 at codons 369-371 appear to accumulate during PI therapy [54,77], but they have not been associated with virological failure to PI therapy. They have also not been observed during in vitro selections with PIs or have demonstrated to contribute to PI resistance. The p2 mutations that accumulate during PI therapy are located in a proposed alpha helical structure spanning the CA/p2 CS [54]. Therefore, the selection by PIs of these mutations might be explained by changes in the stability or the conformation of the alpha helical structure influencing the accessibility of the CA/p2 CS by the viral PR.

NC

Amino acid substitutions in NC have been associated with NFV failure (I389T and I401V [77]). Other mutations in 
NC have been selected in vitro with APV (V390A/D and R409K [59,60]) and GS-8374(I401T and R409K [64]). None of these mutations demonstrated to confer PI resistance and their contribution to PI therapy failure and PI resistance remains unclear.

\section{p1}

Mutations in p1 outside its cleavage sites have not been described to be associated to PI exposure and resistance, in vivo or in vitro.

\section{p6-gag}

Only a handful of mutations in p6 have been described in relation to PI exposure in vivo (NFV; Q474L, A487S and P497L [77]) and in vitro (APV; E468K [59]). E468K in combination with other mutations improves viral replication in the presence of PIs, but the mechanism has not been elucidated [59].

One paper describes (partial) duplication of the $\mathrm{P}(\mathrm{S} / \mathrm{T}) \mathrm{APP}$ motif in relation to PI therapy response. $\mathrm{P}(\mathrm{S} / \mathrm{T}) \mathrm{APP}$ is a proline rich domain in p6-gag (Gag aa 455-459) that recruits Tsg101, a cellular factor involved in HIV budding. The authors found a significant association of partial or complete $\mathrm{P}(\mathrm{S} / \mathrm{T}) \mathrm{APP}$ duplication with a decrease in virological response to APV at week 12 in highly pre-treated but APV naïve patients [95]. In addition, $\mathrm{P}(\mathrm{S} / \mathrm{T})$ APP duplications were significantly associated with the presence of a mutation at V82 in PR. The hypothesized mechanism is an increase in viral packaging efficiency and budding, leading to an enhanced viral fitness. One other study describes an accumulation of $\mathrm{P}(\mathrm{S} / \mathrm{T}) \mathrm{APP}$ insertions/duplications during HAART, but it does not comment on the type of antiretroviral therapy [96]. In contrast, three other studies did not observe a correlation between $\mathrm{P}(\mathrm{S} / \mathrm{T}) \mathrm{APP}$ duplications and antiretroviral therapy [97-99], and one study even found a non-significant trend that HIV-1 patients harbouring $\mathrm{P}(\mathrm{S} / \mathrm{T}) \mathrm{APP}$ insertions were less likely to experience virological failure [100].

\section{Impact of Gag mutations on PI therapy}

Only a few studies investigated the impact of Gag mutations on viral response during subsequent PI therapy. We summarize the available data of CS substitutions at MA codon 128, substitutions in p2/NC (codon 373), $\mathrm{NC} / \mathrm{p} 1$ (codons 428, 431 and 437), p1/p6 (codons, 449, 451,452 and 453) and non-CS p6Gag substitutions at codon 484 .

Mutations at MA/CA CS 128 (3.5\% natural variability in subtype B isolates (Table 1)) were negatively associated with virological response in ANRS 127, a trial involving naïve patients receiving one of two dual-boosted PI combinations (FPV/ATV/r or SQV/ATV/r) [56]. Mutation V128I was also observed in $>10 \%$ of virological rebounders in an analysis of the combined POWER 1,2 and 3 trials that evaluated virological response to DRV/r plus optimized background therapy in PI-experienced patients [66].

Mutation S373Q (codon 373 is highly polymorphic, $36 \%$ variability in subtype B isolates (Table 1)) in the $\mathrm{p} 2 /$ $\mathrm{NC}$ CS, which was associated with the emergence of specific PR mutations during SQV therapy (K20R/I/M and L89M/I) did not have an effect on the virological response. In contrast, mutation S373P negatively impacted virological response to SQV [78].

The frequently observed NC/p1 CS mutation A431V (highly conserved, $0.5 \%$ variability in subtype B isolates (Table 1)) was not associated with a poorer virological outcome in several studies $[10,78]$ and remarkably, was correlated with a better outcome to DRV/r therapy [101].

Analysis of the NARVAL trial [102] revealed that mutation I437V (5.5\% natural variability in subtype B isolates (Table 1)) was significantly associated with a reduced virological response to different PI therapies (RTV, IDV, NFV, SQV and APV) [10]. It was also associated with virological failure in patients on DRV containing therapy in absence of multiple primary DRV resistance mutations in the viral PR [103]. Conversely, mutations at this position in the pol open reading frame (CS TFP/p6pol) positively impacted virological response to double boosted PI therapy (FPV/ATV/r or $\mathrm{SQV} / \mathrm{ATV} / \mathrm{r}$ ) [56].

The study on ANRS 127 also revealed a negative association of CS p1/p6 mutation L449P (9.1\% natural variability in subtype B isolates (Table 1)) on virological response to (FPV/ATV/r and SQV/ATV/r) [56]. In addition, mutations E428G, S451T and R452S (2.3, 22.8 and $0 \%$ natural variability in subtype $B$ isolates (Table 1 )) were linked with a reduced response to $\mathrm{DRV} / \mathrm{r}$ in the POWER trials [66]. In contrast mutations S451G/N/R were associated to a better virological outcome in patients receiving first-line LPV/r monotherapy [88]. This study also showed a negative effect on virological response to LPV/r monotherapy of non-CS Gag mutations at codon $484(\mathrm{~V} 484 \mathrm{G} / \mathrm{I} / \mathrm{P} / \mathrm{S})$.

Mutations at codon $453(8.4 \%$ natural variability in subtype B isolates (Table 1)) were not associated with virological response $[57,78]$.

\section{Maturation inhibitors}

Similar to PIs, the novel class of maturation inhibitors prevents viral replication by inhibiting particle maturation, but instead of targeting the viral PR, they target the Gag and GagPol precursor proteins directly. Within this experimental class of antiretrovirals, the CA assembly inhibitors and CA/p2 inhibitors are the most advanced in their development. CA assembly inhibitors are thought to bind $\mathrm{CA}$ and inhibit particle maturation 
by interfering with CA-CA interactions required for the formation of the conical-shaped capsid core. The CA subunits consist of two domains, the $\mathrm{N}$-terminal and C-terminal domains (NTD and CTD). The mature capsid is constructed as a lattice of hexamers and NTD-NTD, NTD-CTD as well as CTD-CTD interactions are required to build the hexamer lattice $[104,105]$. Binding of the CA assembly inhibitor disrupts the molecular interface between the functional $\mathrm{N}$-terminal and C-terminal structures of CA, which are located adjacently in the hexamer lattice, thereby preventing core assembly. Both small molecules and peptide derivatives are being investigated as potential CA assembly inhibitors and examples of CA assembly inhibitors that were or are in development are: CAP-1 [106,107], CAI [108], NYAD-I [109], BI-257, BI-627 and BI-720 from BoehringerIngelheim [110], PF3450074 from Pfizer [111,112] and CAC1, CAC1M and H8 [113].

As the name suggests, CA/p2 inhibitors impede particle maturation by specifically blocking the cleavage of CA from $\mathrm{p} 2$, which is one of the final and rate-limiting steps in the Gag processing cascade (Figure 1). Unprocessed CA/p2 (p25) interferes with core assembly and results in the formation of non-infectious particles [91,114]. Most data on $\mathrm{CA} / \mathrm{p} 2$ inhibitors are derived from work on bevirimat (BVM, Panacos PA-457, Myriad MPC-4326), which was the most advanced maturation inhibitor in its development (phase II clinical trials). Western blotting and in vitro resistance selection studies identified $\mathrm{CA} / \mathrm{p} 2$ as the target region of bevirimat [71,114], which was later confirmed by cross-linking studies [115]. It has also been shown that bevirimat has a stabilizing effect on the immature Gag lattice which indicates that bevirimat already binds during assembly and must be incorporated to inhibit maturation [116]. This observation offers an explanation why CA/p2 inhibitors are unable to inhibit the processing of monomeric Gag in solution. CA/p2 inhibitors include bevirimat, PA1050040 which is a second generation maturation inhibitor from Panacos [117] based on bevirimat, two maturation inhibitors from Myriad Pharmaceuticals, Vivecon (MPC-9055) [118,119] and MPI-461359 [120], and PF-46396 [121] from Pfizer.

The initial in vitro selection studies with bevirimat identified resistance mutations in the CA/p2 CS at Gag positions 358, 363, 364 and 366 [71]. A more recent study identified additional resistance mutations at Gag codons 362, 368 and 370 [69]. Phase 2b clinical studies demonstrated that baseline polymorphisms (substitution and/or deletions) slightly downstream of the $\mathrm{CA} / \mathrm{p} 2$ cleavage site (Gag p2 aa 369, 370 and 371, known as the QVT-motif) also confer resistance [72,122]. All currently known bevirimat resistance mutations are located in or near the CA/p2 CS (Gag 359-368) (Table 2
[69-72,122,123]). The genetic barrier of $\mathrm{CA} / \mathrm{p} 2$ maturation inhibitors appears to be low. Most single resistance mutations confer high levels of resistance. This is confirmed by the in vitro studies where, in contrast to protease and integrase inhibitors, during in vitro selections with bevirimat, no accumulation of mutations is observed.

\section{Impact of Gag mutations on CA/p2 maturation inhibitor susceptibility}

Several amino acid positions in Gag that are known to affect $\mathrm{CA} / \mathrm{p} 2$ maturation inhibitor susceptibility are highly polymorphic, including codons 362,370 and 371 (Table 1). In the treatment-naïve population, approximately $30 \%$ of patients infected with subtype B harbored an isolate with at least one mutation associated with a reduced susceptibility to bevirimat [54], and this appears to be much higher in non-B subtypes with a prevalence ranging from over $70 \%$ to as high as $93 \%[124,125]$.

Although PIs and maturation inhibitors have a different target site, this review clearly indicates that PI exposure can result in selection of mutations in Gag, including the $\mathrm{CA} / \mathrm{p} 2$ cleavage site which affects $\mathrm{CA} / \mathrm{p} 2$ maturation inhibitor susceptibility (Table 2). Several studies showed an accumulation of bevirimat resistance mutations during PI treatment in bevirimat naïve patients $[54,124,126]$. These mutations were mainly observed in the QVT-motif. In subtype B isolates with PI resistance, the prevalence of bevirimat resistance mutations increased to $45 \%$, a statistically significant increase. Accumulation of mutations at 4 individual positions in the $\mathrm{CA} / \mathrm{p} 2$ region was also statistically significant and involved amino acid substitutions S368C, Q369H, V370A and S373P (Table 2 [54]). In addition, mutations associated with bevirimat resistance were significantly more detected in HIV isolates with $\geq 3$ PI resistance mutations than in those with less than three PI mutations [54,124].

The data presented in this review show that the $\mathrm{CA} / \mathrm{p} 2$ region is variable and affected by PI exposure. A reduced maturation inhibitor activity can be expected in one-third of the treatment-naïve HIV-1 subtype $\mathrm{B}$ isolates and significantly more in PI resistant HIV. Moreover, one could speculate that even in those individuals who do not have mutations in the $\mathrm{CA} / \mathrm{p} 2$ region, mutations in the viral $\mathrm{PR}$ may affect subsequent resistance development to the $\mathrm{CA} / \mathrm{p} 2$ maturation inhibitor. One study demonstrated that an impaired Gag processing efficiency caused by PI resistance mutations, delayed the development of bevirimat resistance and reduced the level of bevirimat resistance conferred by bevirimat resistance mutations [127]. Conversely, we showed that an increased Gag processing efficiency can result in enhanced levels of bevirimat resistance [69]. 
Mutations at codons 362 and 368 give rise to low level bevirimat resistance (2-6 fold) in the presence of wild type $\mathrm{PR}$, whereas in the presence of a drug resistant HIV PR with increased Gag processing bevirimat resistance increases to $>150$ fold [69]. This intricate relation between HIV PR and Gag cleavage is supported by a study by Doyon et al., who also demonstrated that a $\mathrm{CA} / \mathrm{p} 2$ mutation at position 362 has differential effects on $\mathrm{CA} / \mathrm{p} 2$ processing depending on the genotype of the protease present in the virus [68].

\section{Conclusions}

In conclusion, these studies indicate that during PI exposure, mutations in the target region of the $\mathrm{CA} / \mathrm{p} 2$ inhibitors may be selected, reducing the baseline susceptibility to the maturation inhibitor. Furthermore, the level of Gag processing of a PI resistant isolate may impact the development of bevirimat resistance.

\section{Clinical perspective}

This review highlights the complex interactions between the viral protease and its Gag substrates and how mutations in Gag can affect PI and maturation inhibitor susceptibility. The data summarized in this review clearly show that mutations in Gag accumulate during PI therapy and that these mutations can contribute to PI susceptibility. Even though contemporary therapy success rates are very high and development of primary resistance to PI containing HAART is rare, the relative high incidence of unexplained failure without major PI resistance mutations in PR supports including Gag in the resistance analysis.

Especially, the addition of the C-terminal region of Gag (NC/p1 and p1/p6gag CSs) to routine testing could substantially improve our knowledge on genetic variability and the predictive value of genotypic resistance testing. However, this coins a paradox as the actual contribution of Gag mutations to virological failure is largely unknown, and this question can only be answered by including Gag in genotypic testing in clinical trials and cohorts.

HIV maturation inhibitors target the Gag proteins directly, and therefore genotypic analysis of Gag is invaluable for the development and clinical implementation of these inhibitors. This review illustrates that naturally occurring Gag polymorphisms dramatically affect the susceptibility to maturation inhibitors in clinical studies. Furthermore, accumulation of mutations at these polymorphic positions in Gag is observed during PI therapy failure, strongly affecting the sequential utilization of maturation inhibitors. New and more potent maturation inhibitors should therefore overcome the resistance associated with these highly variable positions in Gag and exhibit synergy with protease inhibitors. They should capitalize on the reduced processing often caused by PI resistance mutations in such a way that there is added value from the use of a maturation inhibitor in salvage therapy for PI experienced patients.

\section{Abbreviations}

HIV: Human Immunodeficiency Virus; PR: Protease; MA: Matrix; CA: Capsid; NC: Nucleocapsid; RT: Reverse transcriptase; IN: Integrase; CS: Cleavage sites; PI: Protease inhibitor; HAART: Highly active antiretroviral therapy; NRTI: Nucleoside reverse transcriptase inhibitor; NNRTI: Non-nucleoside reverse transcriptase inhibitor; NTD: N-terminal domain; CTD: C-terminal Domain; BVM: Bevirimat.

\section{Competing interests}

The authors declare they have no competing interests.

\section{Authors' contributions}

AF and MN wrote the manuscript. AMJW modified and contributed parts of the manuscript in her role as clinical virologist. JV reviewed the literature and contributed parts of the manuscript. All authors read and approved the final manuscript.

\section{Acknowledgements}

The Netherlands Organization for Scientific Research (NWO VIDI grant 91796349). NWO had no role in the study design, data collection and analysis, decision to publish, or preparation of the manuscript.

\section{Author details}

${ }^{1}$ Department of Virology, Medical Microbiology, University Medical Center Utrecht, HP G04.614, Heidelberglaan 100, Utrecht 3584 CX, The Netherlands.

${ }^{2}$ Institute of Virology, University of Cologne, Cologne, Germany.

Received: 8 May 2012 Accepted: 17 July 2012

Published: 6 August 2012

\section{References}

1. Jacks T, Power MD, Masiarz FR, Luciw PA, Barr PJ, Varmus HE: Characterization of ribosomal frameshifting in HIV-1 gag-pol expression. Nature 1988, 331:280-283.

2. Prabu-Jeyabalan M, Nalivaika E, Schiffer CA: Substrate shape determines specificity of recognition for HIV-1 protease: analysis of crystal structures of six substrate complexes. Structure 2002, 10:369-381.

3. Krausslich HG, Ingraham RH, Skoog MT, Wimmer E, Pallai PV, Carter CA: Activity of purified biosynthetic proteinase of human immunodeficiency virus on natural substrates and synthetic peptides. Proc Natl Acad Sci U S A 1989, 86:807-811.

4. Pettit SC, Moody MD, Wehbie RS, Kaplan AH, Nantermet PV, Klein CA, Swanstrom R: The p2 domain of human immunodeficiency virus type 1 Gag regulates sequential proteolytic processing and is required to produce fully infectious virions. J Virol 1994, 68:8017-8027.

5. Wiegers K, Rutter G, Kottler H, Tessmer U, Hohenberg H, Krausslich HG: Sequential steps in human immunodeficiency virus particle maturation revealed by alterations of individual Gag polyprotein cleavage sites. J Virol 1998, 72:2846-2854.

6. Pettit SC, Lindquist JN, Kaplan AH, Swanstrom R: Processing sites in the human immunodeficiency virus type 1 (HIV-1) Gag-Pro-Pol precursor are cleaved by the viral protease at different rates. Retrovirology 2005, 2:66.

7. Ozen A, Haliloglu T, Schiffer CA: Dynamics of preferential substrate recognition in HIV-1 protease: redefining the substrate envelope. J Mol Biol 2011, 410:726-744.

8. Pettit SC, Henderson GJ, Schiffer CA, Swanstrom R: Replacement of the P1 amino acid of human immunodeficiency virus type $1 \mathrm{Gag}$ processing sites can inhibit or enhance the rate of cleavage by the viral protease. J Virol 2002, 76:10226-10233.

9. Maguire MF, Guinea R, Griffin P, Macmanus S, Elston RC, Wolfram J, Richards N, Hanlon MH, Porter DJ, Wrin T, Parkin N, Tisdale M, Furfine E, Petropoulos C, Snowden BW, Kleim JP: Changes in human immunodeficiency virus type 1 Gag at positions L449 and P453 are linked to I50V protease mutants in vivo and cause reduction of sensitivity to amprenavir and improved viral fitness in vitro. J Virol 2002, 76:7398-7406. 
10. Nijhuis $M$, van Maarseveen NM, Lastere $S$, Schipper P, Coakley E, Glass B, Rovenska M, de Jong D, Chappey C, Goedegebuure IW, Heilek-Snyder G, Dulude D, Cammack N, Brakier-Gingras L, Konvalinka J, Parkin N, Krausslich HG, Brun-Vezinet F, Boucher CA: A novel substrate-based HIV-1 protease inhibitor drug resistance mechanism. PLoS Med 2007, 4:e36.

11. Shibata J, Sugiura W, Ode H, Iwatani Y, Sato H, Tsang H, Matsuda M, Hasegawa N, Ren F, Tanaka H: Within-host co-evolution of Gag P453L and protease D30N/N88D demonstrates virological advantage in a highly protease inhibitor-exposed HIV-1 case. Antiviral Res 2011, 90:33-41.

12. Dam E, Quercia R, Glass B, Descamps D, Launay O, Duval X, Krausslich HG, Hance AJ, Clavel F: Gag mutations strongly contribute to HIV-1 resistance to protease inhibitors in highly drug-experienced patients besides compensating for fitness loss. PLoS Pathog 2009, 5:e1000345.

13. van Maarseveen NM, Andersson D, Lepsik M, Fun A, Schipper PJ, de Jong D, Boucher CA, Nijhuis M: Modulation of HIV-1 Gag NC/p1 cleavage efficiency affects protease inhibitor resistance and viral replicative capacity. Retrovirology 2012, 9:29.

14. Navia MA, Fitzgerald PM, McKeever BM, Leu CT, Heimbach JC, Herber WK Sigal IS, Darke PL, Springer JP: Three-dimensional structure of aspartyl protease from human immunodeficiency virus HIV-1. Nature 1989, 337:615-620.

15. Wlodawer A, Miller M, Jaskolski M, Sathyanarayana BK, Baldwin E, Weber IT, Selk LM, Clawson L, Schneider J, Kent SB: Conserved folding in retroviral proteases: crystal structure of a synthetic HIV-1 protease. Science 1989, 245:616-621.

16. Pettit SC, Everitt LE, Choudhury S, Dunn BM, Kaplan AH: Initial cleavage of the human immunodeficiency virus type $1 \mathrm{GagPol}$ precursor by its activated protease occurs by an intramolecular mechanism. J Virol 2004 78:8477-8485

17. Tang C, Louis JM, Aniana A, Suh JY, Clore GM: Visualizing transient events in amino-terminal autoprocessing of HIV-1 protease. Nature 2008, 455:693-696.

18. Craig JC, Duncan IB, Hockley D, Grief C, Roberts NA, Mills JS: Antiviral properties of Ro 31-8959, an inhibitor of human immunodeficiency virus (HIV) proteinase. Antiviral Res 1991, 16:295-305.

19. Vacca JP, Dorsey BD, Schleif WA, Levin RB, McDaniel SL, Darke PL, Zugay J, Quintero JC, Blahy OM, Roth E, et al: L-735,524: an orally bioavailable human immunodeficiency virus type 1 protease inhibitor. Proc Natl Acad Sci U S A 1994, 91:4096-4100.

20. Partaledis JA, Yamaguchi K, Tisdale M, Blair EE, Falcione C, Maschera B, Myers RE, Pazhanisamy S, Futer O, Cullinan AB, et al: In vitro selection and characterization of human immunodeficiency virus type 1 (HIV-1) isolates with reduced sensitivity to hydroxyethylamino sulfonamide inhibitors of HIV-1 aspartyl protease. J Virol 1995, 69:5228-5235.

21. Kempf DJ, Marsh KC, Denissen JF, McDonald E, Vasavanonda S, Flentge CA Green BE, Fino L, Park CH, Kong XP, et al: ABT-538 is a potent inhibitor of human immunodeficiency virus protease and has high oral bioavailability in humans. Proc Natl Acad Sci U S A 1995, 92:2484-2488.

22. Patick AK, Mo H, Markowitz M, Appelt K, Wu B, Musick L, Kalish V, Kaldor S, Reich S, Ho D, Webber S: Antiviral and resistance studies of AG1343, an orally bioavailable inhibitor of human immunodeficiency virus protease. Antimicrob Agents Chemother 1996, 40:292-297.

23. Sham HL, Kempf DJ, Molla A, Marsh KC, Kumar GN, Chen CM, Kati W, Stewart K, Lal R, Hsu A, Betebenner D, Korneyeva M, Vasavanonda S, McDonald E, Saldivar A, Wideburg N, Chen X, Niu P, Park C, Jayanti V, Grabowski B, Granneman GR, Sun E, Japour AJ, Leonard JM, Plattner JJ, Norbeck DW: ABT-378, a highly potent inhibitor of the human immunodeficiency virus protease. Antimicrob Agents Chemother 1998, 42:3218-3224.

24. Robinson BS, Riccardi KA, Gong YF, Guo Q, Stock DA, Blair WS, Terry BJ, Deminie CA, Djang F, Colonno RJ, Lin PF: BMS-232632, a highly potent human immunodeficiency virus protease inhibitor that can be used in combination with other available antiretroviral agents. Antimicrob Agents Chemother 2000, 44:2093-2099.

25. Koh $Y$, Nakata $H$, Maeda K, Ogata H, Bilcer G, Devasamudram T, Kincaid JF, Boross P, Wang YF, Tie Y, Volarath P, Gaddis L, Harrison RW, Weber IT, Ghosh AK, Mitsuya $\mathrm{H}$ : Novel bis-tetrahydrofuranylurethane-containing nonpeptidic protease inhibitor (PI) UIC-94017 (TMC114) with potent activity against multi-PI-resistant human immunodeficiency virus in vitro. Antimicrob Agents Chemother 2003, 47:3123-3129.
26. Turner SR, Strohbach JW, Tommasi RA, Aristoff PA, Johnson PD, Skulnick HI, Dolak LA, Seest EP, Tomich PK, Bohanon MJ, Horng MM, Lynn JC, Chong KT, Hinshaw RR, Watenpaugh KD, Janakiraman MN, Thaisrivongs S: Tipranavir (PNU-140690): a potent, orally bioavailable nonpeptidic HIV protease inhibitor of the 5,6-dihydro-4-hydroxy-2-pyrone sulfonamide class. J Med Chem 1998, 41:3467-3476.

27. Koh Y, Matsumi S, Das D, Amano M, Davis DA, Li J, Leschenko S, Baldridge A, Shioda T, Yarchoan R, Ghosh AK, Mitsuya H: Potent inhibition of HIV-1 replication by novel non-peptidyl small molecule inhibitors of protease dimerization. J Biol Chem 2007, 282:28709-28720.

28. Louis JM, Aniana A, Weber IT, Sayer JM: Inhibition of autoprocessing of natural variants and multidrug resistant mutant precursors of HIV-1 protease by clinical inhibitors. Proc Natl Acad Sci U S A 2011, 108:9072-9077.

29. Davis DA, Soule EE, Davidoff KS, Daniels SI, Naiman NE, Yarchoan R: Activity of Human Immunodeficiency Virus Type 1 Protease Inhibitors against the Initial Autocleavage in Gag-Pol Polyprotein Processing. Antimicrob Agents Chemother 2012, 56:3620-3628.

30. Palella FJ Jr, Delaney KM, Moorman AC, Loveless MO, Fuhrer J, Satten GA, Aschman DJ, Holmberg SD: Declining morbidity and mortality among patients with advanced human immunodeficiency virus infection. HIV Outpatient Study Investigators. N Engl J Med 1998, 338:853-860.

31. Kempf DJ, Marsh KC, Kumar G, Rodrigues AD, Denissen JF, McDonald E, Kukulka MJ, Hsu A, Granneman GR, Baroldi PA, Sun E, Pizzuti D, Plattner JJ, Norbeck DW, Leonard JM: Pharmacokinetic enhancement of inhibitors of the human immunodeficiency virus protease by coadministration with ritonavir. Antimicrob Agents Chemother 1997, 41:654-660.

32. van Heeswijk RP, Veldkamp A, Mulder JW, Meenhorst PL, Lange JM, Beijnen $\mathrm{JH}$, Hoetelmans RM: Combination of protease inhibitors for the treatment of HIV-1-infected patients: a review of pharmacokinetics and clinical experience. Antivir Ther 2001, 6:201-229.

33. Larder BA, Hertogs $\mathrm{K}$, Bloor S, van den Eynde CH, DeCian W, Wang Y, Freimuth WW, Tarpley G: Tipranavir inhibits broadly protease inhibitor-resistant HIV-1 clinical samples. AIDS 2000, 14:1943-1948.

34. De Meyer S, Azijn H, Fransen E, De Baere I, Van Ginderen M, Maes B, de Bethune MP: The pathway leading to TMC114 resistance is different for TMC114 compared with other protease inhibitors. Antivir Ther 2006, 11:S24.

35. Surleraux DL, Tahri A, Verschueren WG, Pille GM, de Kock HA, Jonckers TH, Peeters A, De Meyer S, Azijn H, Pauwels R, de Bethune MP, King NM, Prabu-Jeyabalan M, Schiffer CA, Wigerinck PB: Discovery and selection of TMC114, a next generation HIV-1 protease inhibitor. J Med Chem 2005, 48:1813-1822.

36. De Meyer S, Azijn H, Surleraux D, Jochmans D, Tahri A, Pauwels R, Wigerinck $P$, de Bethune MP: TMC114, a novel human immunodeficiency virus type 1 protease inhibitor active against protease inhibitor-resistant viruses, including a broad range of clinical isolates. Antimicrob Agents Chemother 2005, 49:2314-2321.

37. Kolli M, Lastere S, Schiffer CA: Co-evolution of nelfinavir-resistant HIV-1 protease and the p1-p6 substrate. Virology 2006, 347:405-409.

38. Prabu-Jeyabalan M, Nalivaika EA, Romano K, Schiffer CA: Mechanism of substrate recognition by drug-resistant human immunodeficiency virus type 1 protease variants revealed by a novel structural intermediate. J Virol 2006, 80:3607-3616.

39. Nalam MN, Ali A, Altman MD, Reddy GS, Chellappan S, Kairys V, Ozen A, Cao $H$, Gilson MK, Tidor B, Rana TM, Schiffer CA: Evaluating the substrateenvelope hypothesis: structural analysis of novel HIV-1 protease inhibitors designed to be robust against drug resistance. J Virol 2010, 84:5368-5378

40. Gulnik SV, Suvorov LI, Liu B, Yu B, Anderson B, Mitsuya H, Erickson JW: Kinetic characterization and cross-resistance patterns of HIV-1 protease mutants selected under drug pressure. Biochemistry 1995, 34:9282-9287.

41. Croteau G, Doyon L, Thibeault D, McKercher G, Pilote L, Lamarre D: Impaired fitness of human immunodeficiency virus type 1 variants with high-level resistance to protease inhibitors. J Virol 1997, 71:1089-1096.

42. Mahalingam B, Louis JM, Reed CC, Adomat JM, Krouse J, Wang YF, Harrison RW, Weber IT: Structural and kinetic analysis of drug resistant mutants of HIV-1 protease. Eur J Biochem 1999, 263:238-245.

43. Borman AM, Paulous S, Clavel F: Resistance of human immunodeficiency virus type 1 to protease inhibitors: selection of resistance mutations in the presence and absence of the drug. J Gen Virol 1996, 77(Pt 3):419-426. 
44. Doyon L, Croteau G, Thibeault D, Poulin F, Pilote L, Lamarre D: Second locus involved in human immunodeficiency virus type 1 resistance to protease inhibitors. J Virol 1996, 70:3763-3769.

45. Zhang YM, Imamichi H, Imamichi T, Lane HC, Falloon J, Vasudevachari MB, Salzman NP: Drug resistance during indinavir therapy is caused by mutations in the protease gene and in its Gag substrate cleavage sites. J Virol 1997, 71:6662-6670.

46. Mammano F, Petit C, Clavel F: Resistance-associated loss of viral fitness in human immunodeficiency virus type 1: phenotypic analysis of protease and gag coevolution in protease inhibitor-treated patients. J Virol 1998 72:7632-7637

47. Nijhuis M, Schuurman R, de Jong D, Erickson J, Gustchina E, Albert J, Schipper P, Gulnik S, Boucher CA: Increased fitness of drug resistant HIV-1 protease as a result of acquisition of compensatory mutations during suboptimal therapy. AIDS 1999, 13:2349-2359.

48. Mammano F, Trouplin V, Zennou V, Clavel F: Retracing the evolutionary pathways of human immunodeficiency virus type 1 resistance to protease inhibitors: virus fitness in the absence and in the presence of drug. J Virol 2000, 74:8524-8531.

49. Prado JG, Wrin T, Beauchaine J, Ruiz L, Petropoulos CJ, Frost SD, Clotet B, D'Aquila RT, Martinez-Picado J: Amprenavir-resistant HIV-1 exhibits lopinavir cross-resistance and reduced replication capacity. AIDS 2002, 16:1009-1017.

50. Gupta RK, Kohli A, McCormick AL, Towers GJ, Pillay D, Parry CM: Full-length HIV-1 Gag determines protease inhibitor susceptibility within in vitro assays. AIDS 2010, 24:1651-1655.

51. Cote HC, Brumme ZL, Harrigan PR: Human immunodeficiency virus type 1 protease cleavage site mutations associated with protease inhibitor cross-resistance selected by indinavir, ritonavir, and/or saquinavir. J Virol 2001, 75:589-594.

52. de Oliveira T, Engelbrecht S, Janse van Rensburg E, Gordon M, Bishop K, zur Megede J, Barnett SW, Cassol S: Variability at human immunodeficiency virus type 1 subtype $C$ protease cleavage sites: an indication of viral fitness? J Virol 2003, 77:9422-9430.

53. Verheyen J, Knops E, Kupfer B, Hamouda O, Somogyi S, Schuldenzucker U, Hoffmann D, Kaiser R, Pfister H, Kucherer C: Prevalence of C-terminal gag cleavage site mutations in HIV from therapy-naive patients. J Infect 2009 58:61-67.

54. Verheyen J, Verhofstede C, Knops E, Vandekerckhove L, Fun A, Brunen D, Dauwe K, Wensing AM, Pfister H, Kaiser R, Nijhuis M: High prevalence of bevirimat resistance mutations in protease inhibitor-resistant HIV isolates. AIDS 2010, 24:669-673.

55. Kolli M, Stawiski E, Chappey C, Schiffer CA: Human immunodeficiency virus type 1 protease-correlated cleavage site mutations enhance inhibitor resistance. J Virol 2009, 83:11027-11042.

56. Larrouy L, Chazallon C, Landman R, Capitant C, Peytavin G, Collin G, Charpentier C, Storto A, Pialoux G, Katlama C, Girard PM, Yeni P, Aboulker JP, Brun-Vezinet F, Descamps D: Gag mutations can impact virological response to dual-boosted protease inhibitor combinations in antiretroviral-naive HIV-infected patients. Antimicrob Agents Chemother 2010, 54:2910-2919.

57. Bally F, Martinez R, Peters S, Sudre P, Telenti A: Polymorphism of HIV type 1 gag p7/p1 and p1/p6 cleavage sites: clinical significance and implications for resistance to protease inhibitors. AlDS Res Hum Retroviruses 2000, 16:1209-1213.

58. Lambert-Niclot S, Flandre P, Valantin MA, Peytavin G, Sayon S, MorandJoubert L, Delaugerre C, Algarte-Genin M, Katlama C, Calvez V, Marcelin AG: Resistant minority species are rarely observed in patients on darunavir/ ritonavir monotherapy. J Antimicrob Chemother 2012, 67:1470-1474.

59. Gatanaga H, Suzuki Y, Tsang H, Yoshimura K, Kavlick MF, Nagashima K, Gorelick RJ, Mardy S, Tang C, Summers MF, Mitsuya H: Amino acid substitutions in Gag protein at non-cleavage sites are indispensable for the development of a high multitude of HIV-1 resistance against protease inhibitors. J Biol Chem 2002, 277:5952-5961.

60. Aoki M, Venzon DJ, Koh Y, Aoki-Ogata H, Miyakawa T, Yoshimura K, Maeda $\mathrm{K}$, Mitsuya $\mathrm{H}$ : Non-cleavage site gag mutations in amprenavir-resistant human immunodeficiency virus type 1 (HIV-1) predispose HIV-1 to rapid acquisition of amprenavir resistance but delay development of resistance to other protease inhibitors. J Virol 2009, 83:3059-3068.

61. Koh Y, Das D, Leschenko S, Nakata H, Ogata-Aoki H, Amano M, Nakayama M, Ghosh AK, Mitsuya H: GRL-02031, a novel nonpeptidic protease inhibitor (PI) containing a stereochemically defined fused cyclopentanyltetrahydrofuran potent against multi-PI-resistant human immunodeficiency virus type 1 in vitro. Antimicrob Agents Chemother 2009, 53:997-1006.

62. Parry CM, Kolli M, Myers RE, Cane PA, Schiffer C, Pillay D: Three residues in HIV-1 matrix contribute to protease inhibitor susceptibility and replication capacity. Antimicrob Agents Chemother 2011, 55:1106-1113.

63. Parry CM, Kohli A, Boinett CJ, Towers GJ, McCormick AL, Pillay D: Gag determinants of fitness and drug susceptibility in protease inhibitor-resistant human immunodeficiency virus type 1. J Virol 2009, 83:9094-9101.

64. Callebaut $\mathrm{C}$, Stray K, Tsai L, Xu L, Lee W, Cihlar T: In vitro HIV-1 resistance selection to GS8374, a novel phosphonate protease inhibitor: comparison with lopinavir, atazanavir and darunavir. Antivir Ther 2007, 12:S18.

65. Knops E, Daumer M, Awerkiew S, Kartashev V, Schulter E, Kutsev S Brakier-Gingras L, Kaiser R, Pfister $H$, Verheyen J: Evolution of protease inhibitor resistance in the gag and pol genes of HIV subtype $\mathrm{G}$ isolates. J Antimicrob Chemother 2010, 65:1472-1476.

66. Dierynck I, De Meyer S, C-V K, Van Marck H, Lathouwers E, Thys K, Maes B, de Bethune MP: Impact of Gag cleavage site mutations on the virological response to darunavir/ritonavir in treatment-experienced patients in POWER 1, 2 and 3. Antivir Ther 2007, 12:S23.

67. Roquebert B, Malet I, Wirden M, Tubiana R, Valantin MA, Simon A, Katlama C, Peytavin G, Calvez V, Marcelin AG: Role of HIV-1 minority populations on resistance mutational pattern evolution and susceptibility to protease inhibitors. AIDS 2006, 20:287-289.

68. Doyon L, Tremblay S, Bourgon L, Wardrop E, Cordingley MG: Selection and characterization of HIV-1 showing reduced susceptibility to the non-peptidic protease inhibitor tipranavir. Antiviral Res 2005, 68:27-35.

69. Fun A, van Maarseveen NM, Pokorna J, Maas RE, Schipper PJ, Konvalinka J, Nijhuis M: HIV-1 protease inhibitor mutations affect the development of HIV-1 resistance to the maturation inhibitor bevirimat. Retrovirology 2011, 8:70.

70. Margot NA, Gibbs CS, Miller MD: Phenotypic Susceptibility to Bevirimat in Isolates from HIV-1-Infected Patients without Prior Exposure to Bevirimat. Antimicrob Agents Chemother 2010, 54:2345-2353.

71. Adamson CS, Ablan SD, Boeras I, Goila-Gaur R, Soheilian F, Nagashima K, Li F, Salzwedel K, Sakalian M, Wild CT, Freed EO: In vitro resistance to the human immunodeficiency virus type 1 maturation inhibitor PA-457 (Bevirimat). J Virol 2006, 80:10957-10971.

72. Van Baelen K, Salzwedel K, Rondelez E, Van Eygen V, De Vos S, Verheyen A, Steegen K, Verlinden Y, Allaway GP, Stuyver LJ: Susceptibility of human immunodeficiency virus type 1 to the maturation inhibitor bevirimat is modulated by baseline polymorphisms in Gag spacer peptide 1. Antimicrob Agents Chemother 2009, 53:2185-2188.

73. Zhou J, Chen $\mathrm{CH}$, Aiken $\mathrm{C}$ : Human immunodeficiency virus type 1 resistance to the small molecule maturation inhibitor 3-0-(3',3'dimethylsuccinyl)-betulinic acid is conferred by a variety of single amino acid substitutions at the CA-SP1 cleavage site in Gag. J Virol 2006, 80:12095-12101.

74. Salzwedel K, Reddick M, Matallana C, Finnegan C, Adamson C, Sakalian M, Stanley D, Martin D, McCallister S, Freed E, Allaway G: Role of Gag polymorphisms in HIV-1 sensitivity to the maturation inhibitor bevirimat. Antivir Ther 2008, 13:A31

75. Li F, Zoumplis D, Matallana C, Kilgore NR, Reddick M, Yunus AS, Adamson CS, Salzwedel K, Martin DE, Allaway GP, Freed EO, Wild CT: Determinants of activity of the HIV-1 maturation inhibitor PA-457. Virology 2006, 356:217-224.

76. Adamson CS, Sakalian M, Salzwedel K, Freed EO: Polymorphisms in Gag spacer peptide 1 confer varying levels of resistance to the HIV- 1 maturation inhibitor bevirimat. Retrovirology 2010, 7:36.

77. Myint L, Matsuda M, Matsuda Z, Yokomaku Y, Chiba T, Okano A, Yamada K Sugiura W: Gag non-cleavage site mutations contribute to full recovery of viral fitness in protease inhibitor-resistant human immunodeficiency virus type 1. Antimicrob Agents Chemother 2004, 48:444-452.

78. Malet I, Roquebert B, Dalban C, Wirden M, Amellal B, Agher R, Simon A, Katlama C, Costagliola D, Calvez V, Marcelin AG: Association of Gag cleavage sites to protease mutations and to virological response in HIV-1 treated patients. J Infect 2007, 54:367-374.

79. Mo H, Parkin N, Stewart KD, Lu L, Dekhtyar T, Kempf DJ, Molla A: Identification and structural characterization of I84C and I84A mutations 
that are associated with high-level resistance to human immunodeficiency virus protease inhibitors and impair viral replication. Antimicrob Agents Chemother 2007, 51:732-735.

80. Resch W, Parkin N, Watkins T, Harris J, Swanstrom R: Evolution of human immunodeficiency virus type 1 protease genotypes and phenotypes in vivo under selective pressure of the protease inhibitor ritonavir. J Virol 2005, 79:10638-10649.

81. Nijhuis M, Wensing AM, Bierman WF, de Jong D, Kagan R, Fun A, Jaspers CA, Schurink KA, van Agtmael MA, Boucher CA: Failure of treatment with first-line lopinavir boosted with ritonavir can be explained by novel resistance pathways with protease mutation 76 V. J Infect Dis 2009, 200:698-709.

82. Verheyen J, Litau E, Sing T, Daumer M, Balduin M, Oette M, Fatkenheuer G, Rockstroh JK, Schuldenzucker U, Hoffmann D, Pfister H, Kaiser R: Compensatory mutations at the HIV cleavage sites p7/p1 and p1/p6-gag in therapy-naive and therapy-experienced patients. Antivir Ther 2006, 11:879-887.

83. Knops E, Kemper I, Schulter E, Pfister H, Kaiser R, Verheyen J: The evolution of protease mutation $76 \mathrm{~V}$ is associated with protease mutation $46 \mathrm{I}$ and gag mutation 431 V. AIDS 2010, 24:779-781.

84. Watkins T, Resch W, Irlbeck D, Swanstrom R: Selection of high-level resistance to human immunodeficiency virus type 1 protease inhibitors. Antimicrob Agents Chemother 2003, 47:759-769.

85. Carrillo A, Stewart KD, Sham HL, Norbeck DW, Kohlbrenner WE, Leonard JM, Kempf DJ, Molla A: In vitro selection and characterization of human immunodeficiency virus type 1 variants with increased resistance to ABT-378, a novel protease inhibitor. J Virol 1998, 72:7532-7541.

86. Knops E, Brakier-Gingras L, Schulter E, Pfister H, Kaiser R, Verheyen J: Mutational patterns in the frameshift-regulating site of HIV-1 selected by protease inhibitors. Med Microbiol Immunol 2011, 201:213-218.

87. Yates PJ, Hazen R, St Clair M, Boone L, Tisdale M, Elston RC: In vitro development of resistance to human immunodeficiency virus protease inhibitor GW640385. Antimicrob Agents Chemother 2006, 50:1092-1095.

88. Ghosn J, Delaugerre C, Flandre P, Galimand J, Cohen-Codar I, Raffi F, Delfraissy JF, Rouzioux C, Chaix ML: Polymorphism in Gag Gene Cleavage Sites of HIV-1 Non-B Subtype and Virological Outcome of a First-Line Lopinavir/Ritonavir Single Drug Regimen. PLoS One 2011, 6:e24798.

89. Feher A, Weber IT, Bagossi P, Boross P, Mahalingam B, Louis JM, Copeland TD, Torshin IY, Harrison RW, Tozser J: Effect of sequence polymorphism and drug resistance on two HIV-1 Gag processing sites. Eur J Biochem 2002, 269:4114-4120.

90. Prabu-Jeyabalan M, Nalivaika EA, King NM, Schiffer CA: Structural basis for coevolution of a human immunodeficiency virus type 1 nucleocapsid-p1 cleavage site with a V82A drug-resistant mutation in viral protease. $J$ Virol 2004, 78:12446-12454.

91. Muller B, Anders M, Akiyama H, Welsch S, Glass B, Nikovics K, Clavel F, Tervo HM, Keppler OT, Krausslich HG: HIV-1 Gag processing intermediates trans-dominantly interfere with HIV-1 infectivity. J Biol Chem 2009, 284:29692-29703.

92. Moore ML, Bryan WM, Fakhoury SA, Magaard W, Huffman WF, Dayton BD, Meek TD, Hyland L, Dreyer GB, Metcalf BW, et al: Peptide substrates and inhibitors of the HIV-1 protease. Biochem Biophys Res Commun 1989, 159:420-425.

93. Briggs JA, Simon MN, Gross I, Krausslich HG, Fuller SD, Vogt VM, Johnson MC: The stoichiometry of Gag protein in HIV-1. Nat Struct Mol Biol 2004, 11:672-675.

94. Nijhuis M, van Maarseveen NM, de Jong D, Schipper PJ, Goedegebuure IW, Boucher CAB: Substitutions wihin Gag but outside the cleavage sites can cause protease inhibitor resistance. Antivir Ther 2006, 11:S149.

95. Lastere S, Dalban C, Collin G, Descamps D, Girard PM, Clavel F, Costagliola D, Brun-Vezinet F: Impact of insertions in the HIV-1 p6 PTAPP region on the virological response to amprenavir. Antivir Ther 2004, 9:221-227.

96. Martins AN, Arruda MB, Pires AF, Tanuri A, Brindeiro RM: Accumulation of $P$ (T/S)AP late domain duplications in HIV type 1 subtypes $B, C$, and $F$ derived from individuals failing ARV therapy and ARV drug-naive patients. AIDS Res Hum Retroviruses 2011, 27:687-692.

97. Brumme ZL, Chan KJ, Dong WW, Wynhoven B, Mo T, Hogg RS, Montaner JS, O'Shaughnessy MV, Harrigan PR: Prevalence and clinical implications of insertions in the HIV-1 p6Gag N-terminal region in drug-naive individuals initiating antiretroviral therapy. Antivir Ther 2003, 8:91-96.
98. Gallego O, de Mendoza C, Corral A, Soriano V: Changes in the human immunodeficiency virus p7-p1-p6 gag gene in drug-naive and pretreated patients. J Clin Microbio/ 2003, 41:1245-1247.

99. Holguin A, Alvarez A, Soriano V: Variability in the P6gag domains of HIV-1 involved in viral budding. AIDS 2006, 20:624-627.

100. Kaufmann GR, Suzuki K, Cunningham P, Mukaide M, Kondo M, Imai M, Zaunders J, Cooper DA: Impact of HIV type 1 protease, reverse transcriptase, cleavage site, and p6 mutations on the virological response to quadruple therapy with saquinavir, ritonavir, and two nucleoside analogs. AIDS Res Hum Retroviruses 2001, 17:487-497.

101. Larrouy L, Lambert-Niclot S, Charpentier C, Fourati S, Visseaux B, Soulie C, Wirden M, Katlama C, Yeni P, Brun-Vezinet F, Calvez V, Marcelin AG, Descamps D: Positive impact of HIV-1 gag cleavage site mutations on the virological response to darunavir boosted with ritonavir. Antimicrob Agents Chemother 2011, 55:1754-1757.

102. Meynard JL, Vray M, Morand-Joubert L, Race E, Descamps D, Peytavin G, Matheron S, Lamotte C, Guiramand S, Costagliola D, Brun-Vezinet F, Clavel F, Girard PM: Phenotypic or genotypic resistance testing for choosing antiretroviral therapy after treatment failure: a randomized trial. AIDS 2002, 16:727-736.

103. Lambert-Niclot S, Flandre P, Malet I, Canestri A, Soulie C, Tubiana R, Brunet C, Wirden M, Katlama C, Calvez V, Marcelin AG: Impact of gag mutations on selection of darunavir resistance mutations in HIV-1 protease. J Antimicrob Chemother 2008, 62:905-908.

104. Li S, Hill CP, Sundquist WI, Finch JT: Image reconstructions of helical assemblies of the HIV-1 CA protein. Nature 2000, 407:409-413.

105. Briggs JA, Riches JD, Glass B, Bartonova V, Zanetti G, Krausslich HG: Structure and assembly of immature HIV. Proc Natl Acad Sci U S A 2009, 106:11090-11095.

106. Tang C, Loeliger E, Kinde I, Kyere S, Mayo K, Barklis E, Sun Y, Huang M, Summers MF: Antiviral inhibition of the HIV-1 capsid protein. $J$ Mol Biol 2003, 327:1013-1020.

107. Kelly BN, Kyere S, Kinde I, Tang C, Howard BR, Robinson H, Sundquist WI, Summers MF, Hill CP: Structure of the antiviral assembly inhibitor CAP-1 complex with the HIV-1 CA protein. J Mol Biol 2007, 373:355-366.

108. Sticht J, Humbert M, Findlow S, Bodem J, Muller B, Dietrich U, Werner J, Krausslich HG: A peptide inhibitor of HIV-1 assembly in vitro. Nat Struct Mol Biol 2005, 12:671-677.

109. Zhang H, Zhao Q, Bhattacharya S, Waheed AA, Tong X, Hong A, Heck S, Curreli F, Goger M, Cowburn D, Freed EO, Debnath AK: A cell-penetrating helical peptide as a potential HIV-1 inhibitor. J Mol Biol 2008, 378:565-580.

110. Titolo S, Mercier JF, Wardrop E, Schwedler U, Goudreau N, Lemke C, Faucher AM, Yoakim C, Simoneau B, Sundquist WI, Mason S: Discovery of Potent HIV-1 CapsidAssembly Inhibitors. San Francisco, USA: Program \& Abstracts of the 17th Conference on Retroviruses and Opportunistic Infections; 2010. Abstract 50.

111. Blair WS, Pickford C, Irving SL, Brown DG, Anderson M, Bazin R, Cao J, Ciaramella G, Isaacson J, Jackson L, Hunt R, Kjerrstrom A, Nieman JA, Patick AK, Perros M, Scott AD, Whitby K, Wu H, Butler SL: HIV capsid is a tractable target for small molecule therapeutic intervention. PLoS Pathog 2010, 6:e1001220.

112. Shi J, Zhou J, Shah VB, Aiken C, Whitby K: Small-molecule inhibition of human immunodeficiency virus type 1 infection by virus capsid destabilization. J Virol 2011, 85:542-549.

113. Bocanegra R, Nevot M, Domenech R, Lopez I, Abian O, Rodriguez-Huete A, Cavasotto CN, Velazquez-Campoy A, Gomez J, Martinez MA, Neira JL, Mateu MG: Rationally Designed Interfacial Peptides Are Efficient In Vitro Inhibitors of HIV-1 Capsid Assembly with Antiviral Activity. PLoS One 2011, 6:e23877.

114. Li F, Goila-Gaur R, Salzwedel K, Kilgore NR, Reddick M, Matallana C, Castillo A, Zoumplis D, Martin DE, Orenstein JM, Allaway GP, Freed EO, Wild CT: PA-457: a potent HIV inhibitor that disrupts core condensation by targeting a late step in Gag processing. Proc Natl Acad Sci U S A 2003, 100:13555-13560

115. Nguyen AT, Feasley CL, Jackson KW, Nitz TJ, Salzwedel K, Air GM, Sakalian M: The prototype HIV-1 maturation inhibitor, bevirimat, binds to the CA-SP1 cleavage site in immature Gag particles. Retrovirology 2011, 8:101.

116. Keller PW, Adamson CS, Heymann JB, Freed EO, Steven AC: HIV-1 maturation inhibitor bevirimat stabilizes the immature Gag lattice. J Virol 2011, 85:1420-1428. 
117. Kilgore NR, Reddick M, Zuiderhof M, Stanley D, Nitz T, Bullock P, Allaway GP, Martin DE: Characterization of PA1050040, a second-generation HIV-1 maturation inhibitor. Sydney, Australia: IAS 2007, 4th IAS Conference On HIV Pathogenesis, Treatment and Prevention; 2007. Abstract MOPDX05.

118. Beelen AP, Otto J, Fidler M, Sanguinetti E, Smiley P, Balch A, Medlock M, Jackson M, Swabb EA: Phase 1, Single Ascending Oral Dose Study of the Safety, Tolerability, and Pharmacokinetics of a Novel HIV-1 Maturation Inhibitor in HIV Negative Healthy Subjects. Montreal, Canada: Program \& Abstracts of the 16th Conference on Retroviruses and Opportunistic Infections; 2009. Abstract 570.

119. Baichwal V, Austin H, Brown B, McKinnon R, Yager K, Kumar V, Gerrish D, Anderson M, Carlson R: Anti-viral Characterization in vitro of a Novel Maturation Inhibitor, MPC-9055. Montreal, Canada: Program \& Abstracts of the 16th Conference on Retroviruses and Opportunistic Infections; 2009. Abstract 561.

120. Kumar V, Gerrish D, Hoarau C, Yager K, Austin H, McKinnon R, Brown B, Baichwal V, Papac D, Bradford C, Patton S, Bulka K, DeMie L, Carlson R: Next Generation Orally Bioavailable HIV-1 Maturation Inhibitors. San Francisco, USA: 239th ACS National Meeting \& Exposition; 2010. Abstract 137.

121. Blair WS, Cao J, Fok-Seang J, Griffin P, Isaacson J, Jackson RL, Murray E, Patick AK, Peng Q, Perros M, Pickford C, Wu H, Butler SL: New smallmolecule inhibitor class targeting human immunodeficiency virus type 1 virion maturation. Antimicrob Agents Chemother 2009, 53:5080-5087.

122. McCallister S, Lalezari J, Richmond G, Thompson M, Harrigan PR, Martin DE, Salzwedel K, Allaway GP: HIV-1 Gag polymorphisms determine treatment response to bevirimat (PA-457). Antivir Ther 2008, 13:A10.

123. Knapp DJ, Harrigan PR, Poon AF, Brumme ZL, Brockman M, Cheung PK: In Vitro Selection of Clinically Relevant Bevirimat Resistance Mutations Revealed by "Deep" Sequencing of Serially Passaged, Quasispecies-Containing Recombinant HIV-1. J Clin Microbiol 2011, 49:201-208.

124. Seclen E, Gonzalez Mdel M, Corral A, de Mendoza C, Soriano V, Poveda E: High prevalence of natural polymorphisms in Gag (CA-SP1) associated with reduced response to Bevirimat, an HIV-1 maturation inhibitor. AIDS 2010, 24:467-469.

125. Lu W, Salzwedel K, Wang D, Chakravarty S, Freed EO, Wild CT, Li F: A single polymorphism in HIV-1 subtype C SP1 is sufficient to confer natural resistance to the maturation inhibitor bevirimat. Antimicrob Agents Chemother 2011, 55:3324-3329.

126. Malet I, Wirden M, Derache A, Simon A, Katlama C, Calvez V, Marcelin AG: Primary genotypic resistance of HIV- 1 to the maturation inhibitor PA-457 in protease inhibitor-experienced patients. AIDS 2007, 21:871-873.

127. Adamson CS, Waki K, Ablan SD, Salzwedel K, Freed EO: Impact of human immunodeficiency virus type 1 resistance to protease inhibitors on evolution of resistance to the maturation inhibitor bevirimat (PA-457). J Virol 2009, 83:4884-4894.

doi:10.1186/1742-4690-9-63

Cite this article as: Fun et al:: Human Immunodeficiency Virus gag and protease: partners in resistance. Retrovirology 2012 9:63.

\section{Submit your next manuscript to BioMed Central and take full advantage of:}

- Convenient online submission

- Thorough peer review

- No space constraints or color figure charges

- Immediate publication on acceptance

- Inclusion in PubMed, CAS, Scopus and Google Scholar

- Research which is freely available for redistribution 